\title{
A STUDY OF THE FAT METABOLISM OF INFANTS AND YOUNG CHILDREN
}

\author{
I. FAT IN THE STOOLS OF BREAST FED INFANTS* \\ L. EMMETT HOLT, M.D. \\ ANGELIA M. COURTNEY AND HELEN L. FALES \\ NEW YORK
}

In recent years the examination of infants' stools, on the assumption that they represent the completeness of digestion and absorption of the different food constituents, has become a matter of great importance in the study of infant nutrition. Especially is this true in regard to the fat of the stool. It is generally believed that a knowledge of the fat content of stools and the distribution of the fat as soap, free fatty acids and neutral fat is highly desirable from a practical point of view. This knowledge is usually obtained by a superficial clinical examination of the stool and conclusions are frequently drawn from such findings which seem to us to be of questionable value.

There is, however, available in the literature a considerable amount of material which has been obtained by more complete and accurate chemical investigations. For various reasons these findings have not established a definite standard of the composition of infants' stools under varying conditions. In the first place, no very large number of stools has been reported by the same investigator. Moreover, the use of different methods for fat determination interferes with the correlation of the results obtained by various authors. Another difficulty arises from the fact that the greater part of these results have been obtained in Germany, where living conditions and methods of feeding are different from our own.

Reliable figures on the composition of stools of breast fed infants are particularly scanty. Both for this reason and because of the great importance attached to all information concerning the results of breast feeding, it has seemed fitting to begin a general study of the fat metabolism of infants and young children with the examination of a considerable number of stools of breast fed infants. The observations were made with a view to answering the following questions:

1. What is normally the per cent. of total fat and what is the distribution of fat as soap, free fatty acids and neutral fat in the stools of healthy breast fed infants?

* From the Laboratories of the Rockefeller Institute for Medical Research and the Babies' Hospital. 
2. What is the difference in fat content and distribution of fat between normal and abnormal stools?

3. Does the amount and distribution of fat in the stools of healthy breast fed infants vary with the per cent. of fat in the milk and with the amount of fat intake?

The material examined consists of forty-eight collections of feces from thirty-four different infants from 10 days to 10 months of age.

Thirty of these infants were well nourished and, with few exceptions, gaining normally. In the greater number of these cases the appearance of the stools was that typical of normal breast fed infants, largely yellow, granular or pasty, very acid to litmus, with acid aromatic, not unpleasant odor. One child had stools of a peculiar dark orange color. Several of the stools showed more or less mucus and some were partly green in color. A number of the children had distinctly abnormal stools, markedly green in color and containing much mucus.

Table 1.-Total Fat and Fat Distribution in Typically NORMAL YeLlow StOOLS

\begin{tabular}{|c|c|c|c|c|c|c|c|}
\hline \multirow[b]{2}{*}{ Case } & \multirow[b]{2}{*}{ Age } & \multirow{2}{*}{$\begin{array}{c}\text { Fat } \\
\text { per Cent. } \\
\text { of } \\
\text { Dried } \\
\text { Weight }\end{array}$} & \multicolumn{3}{|c|}{ Per Cent. of Total Fat as } & \multirow{2}{*}{$\begin{array}{c}\text { Per } \\
\text { Oent. } \\
\text { Fat in } \\
\text { Mother's } \\
\text { Milk }\end{array}$} & \multirow[b]{2}{*}{ Remarks } \\
\hline & & & Soap & $\begin{array}{c}\text { Free } \\
\text { Fatty } \\
\text { Acids }\end{array}$ & $\underset{\text { Fat }}{\text { Neutral }}$ & & \\
\hline $\begin{array}{l}\text { 1. P. L. } 4 \\
\text { 2. P. L. } 5\end{array}$ & $\begin{array}{l}6 \text { wk. } \\
9 \text { wk. }\end{array}$ & $\begin{array}{l}38.7 \\
29.3\end{array}$ & $\begin{array}{l}74.8 \\
74.0\end{array}$ & $\begin{array}{l}16.6 \\
14.6\end{array}$ & $\begin{array}{r}8.6 \\
11.4\end{array}$ & 3.8 & Had also 4 tsp. dried \\
\hline $\begin{array}{l}\text { 3. W. C. } \\
\text { 4. P. L. } 2 \\
\text { 5. M. E. } \\
\text { 6. P. L. } 3\end{array}$ & $\begin{array}{l}3 \text { mo. } \\
3 \text { wk. } \\
5 \text { mo. } \\
3.5 \text { wk. }\end{array}$ & $\begin{array}{l}26.3 \\
52.0 \\
53.1 \\
41.0\end{array}$ & $\begin{array}{l}70.9 \\
67.7 \\
67.5 \\
63.8\end{array}$ & $\begin{array}{l}16.9 \\
24.4 \\
19.6 \\
25.6\end{array}$ & $\begin{array}{r}12.2 \\
7.9 \\
12.9 \\
10.6\end{array}$ & $\begin{array}{l}2.5 \\
5.6 \\
6.4 \\
4.1\end{array}$ & Milk showed 5.5\% sigar \\
\hline $\begin{aligned} \text { 7. } & \text { L. H. } \\
\text { 8. } & \text { B. T. I } \\
9 . & \text { E. M. } \\
\text { 10. } & \text { B. G. I } \\
11 . & \text { B. G. 3 } \\
\text { 12. } & \text { P. L. I }\end{aligned}$ & $\begin{array}{l}3 \mathrm{mo} . \\
3 \mathrm{wk} . \\
10 \mathrm{wk} . \\
6 \mathrm{mo} . \\
7 \mathrm{mo} . \\
10 \mathrm{da} .\end{array}$ & $\begin{array}{l}29.4 \\
43.2 \\
32.7 \\
43.6 \\
57.7 \\
55.8\end{array}$ & $\begin{array}{l}60.9 \\
57.5 \\
56.9 \\
53.4 \\
52.4 \\
46.8\end{array}$ & $\begin{array}{l}24.3 \\
23.1 \\
21.7 \\
32.7 \\
30.6 \\
35.5\end{array}$ & $\begin{array}{l}14.8 \\
19.4 \\
21.4 \\
13.9 \\
17.0 \\
17.7\end{array}$ & $\begin{array}{l}5.8 \\
2.6 \\
\cdots\end{array}$ & Milk colostrum; a little \\
\hline 13. B. T. 2 & $3.5 \mathrm{wk}$. & 43.7 & 44.5 & 32.3 & 23.2 & 4.3 & $\begin{array}{l}\text { Milk showed 6.8\% sugar } \\
\text { and } 1.4 \% \text { protein }\end{array}$ \\
\hline $\begin{array}{l}\text { 14. B. G. } 2 \\
\text { 15. B. M. }\end{array}$ & $\begin{array}{l}6.5 \mathrm{mo} . \\
8 \mathrm{da} .\end{array}$ & $\begin{array}{l}33.7 \\
51.5\end{array}$ & $\begin{array}{l}40.8 \\
34.8\end{array}$ & $\begin{array}{l}35.5 \\
41.8\end{array}$ & $\begin{array}{l}23.7 \\
23.4\end{array}$ & $\cdots$ & Milk colostrum \\
\hline Average...... & ............ & 42.1 & 67.8 & 26.3 & 15.8 & & \\
\hline
\end{tabular}

Four of the children were acutely ill. One of these, so ill that he died two days later, had stools typically normal in appearance, although the daily amount was unusually large. The others had abnormal stools - green, watery with much mucus.

The collected stools were dried quickly on the water bath to constant weight and ground to a powder. Analyses were made for total fat and its distribution as soap, free fatty acids and neutral fat, according to the method heretofore described by us. ${ }^{1}$

1. Holt, Courtney and Fales: Am. J. Dis. Child. 17:38 (January) 1919. 
The stool findings for the normal children have been arranged in three groups, according to the gross appearance of the stools. The first group, Table 1, includes the analyses of the stools which were typically normal in appearance, showing neither green color nor evident mucus. Two of the infants were under 10 days old, the milk being colostrum.

It is interesting to find that in the normal stools of nursing infants the total fat forms so large a percentage of the dried weight. The average in this table is 42.1 per cent., and there are five instances in which the fat is over 50 per cent. of the total dried weight. This is considerably higher than we have generally found in the case of infants with normal digestion fed on dilutions of cow's milk. The findings as regards the distribution of fat are equally striking. The fat which is soap is high in this group, averaging 57.8 per cent. of the total fat. The neutral fat is rather low, averaging 15.9 per cent. of the total fat. The soap predominates over the other forms of fat in every case but one - an infant receiving colostrum.

TABle 2.-Total Fat and Fat Distribution in Good Stools, Not Quite Normal, That Is, Partly Green or Showing Some Mucus

\begin{tabular}{|c|c|c|c|c|c|c|c|}
\hline \multirow[b]{2}{*}{ Case } & \multirow[b]{2}{*}{ Age } & \multirow{2}{*}{$\begin{array}{c}\text { Fat } \\
\text { per Cent. } \\
\text { of } \\
\text { Dried } \\
\text { Weight }\end{array}$} & \multicolumn{3}{|c|}{ Per Cent. of Total Fat as } & \multirow{2}{*}{$\begin{array}{c}\text { Per } \\
\text { Cent. } \\
\text { Fat in } \\
\text { Mother's } \\
\text { Milk }\end{array}$} & \multirow[b]{2}{*}{ Remarks } \\
\hline & & & Soap & $\begin{array}{l}\text { Free } \\
\text { Fatty } \\
\text { Acids }\end{array}$ & $\underset{\text { Nat }}{\text { Neutral }}$ & & \\
\hline $\begin{array}{ll}\text { 16. } & \text { B. N. } \\
\text { 17. } & \text { D. T. } \\
\text { 18. } & \text { V. V. }\end{array}$ & $\begin{array}{l}7 \text { wk. } \\
6 \text { wk. } \\
5 \text { wk. }\end{array}$ & $\begin{array}{l}36.0 \\
61.1 \\
43.9\end{array}$ & $\begin{array}{l}49.6 \\
47.2 \\
46.0\end{array}$ & $\begin{array}{l}37.5 \\
35.8 \\
41.1\end{array}$ & $\begin{array}{l}12.9 \\
17.0 \\
12.9\end{array}$ & $\begin{array}{l}2.5 \\
\ldots\end{array}$ & Child not in good con- \\
\hline 19. V. R. & $8 \mathrm{mo}$. & 30.8 & & (No sep & & 3.9 & $\begin{array}{l}\text { dition* } \\
\text { Child not gaining at } \\
\text { time }\end{array}$ \\
\hline $\begin{array}{l}\text { 20. N. K. } 2 \\
\text { 21. M. C. }\end{array}$ & $\begin{array}{l}7 \mathrm{wk} . \\
8 \mathrm{wk} .\end{array}$ & $\begin{array}{l}18.6 \\
10.7\end{array}$ & $\begin{array}{l}41.4 \\
39.7\end{array}$ & $\begin{array}{l}35.1 \\
49.5\end{array}$ & $\begin{array}{l}23.5 \\
10.8\end{array}$ & $\begin{array}{l}2.5 \\
3.3\end{array}$ & $\begin{array}{l}\text { time } \\
\text { Stool slightly fermenta- }\end{array}$ \\
\hline 22. M. A. & 4 wk. & 35.7 & 38.3 & 44.6 & 17.1 & 5.6 & $\begin{array}{l}\text { Child not in good con- } \\
\text { dition* }\end{array}$ \\
\hline $\begin{array}{ll}23 . & \text { J. K. } \\
24 . & \text { V. H. } \\
25 . & \text { B. I. } \\
26 . & \text { L. A. } \\
27 . & \text { N. K. } 1\end{array}$ & $\begin{array}{l}5 \text { mo. } \\
9 \text { wk. } \\
8 \text { wk. } \\
5 \text { wk. } \\
6 \text { wk. }\end{array}$ & $\begin{array}{l}32.9 \\
41.3 \\
44.9 \\
45.4 \\
27.3\end{array}$ & $\begin{array}{l}36.4 \\
32.9 \\
31.2 \\
89.0 \\
27.5\end{array}$ & $\begin{array}{l}46.5 \\
47.1 \\
55.2 \\
58.0 \\
55.8\end{array}$ & $\begin{array}{l}17.1 \\
20.0 \\
13.6 \\
13.0 \\
16.7\end{array}$ & $\begin{array}{l}6.4 \\
2.0 \\
5.4 \\
1.4 \\
2.5\end{array}$ & Stools slightly fermen- \\
\hline $\begin{array}{ll}28 . & \text { B. } \\
29 . & \text { R. } \\
30 . & \text { B. W. } \\
\text { 31. } & \text { B. B. }\end{array}$ & $\begin{array}{c}11 \mathrm{wk} . \\
2 \mathrm{mo} . \\
4 \mathrm{wk} . \\
\ldots \ldots .\end{array}$ & $\begin{array}{l}23.3 \\
43.5 \\
38.2 \\
52.3\end{array}$ & $\begin{array}{l}21.4 \\
20.0 \\
19.3 \\
16.8\end{array}$ & $\begin{array}{l}45.6 \\
53.7 \\
51.7 \\
50.0\end{array}$ & $\begin{array}{l}33.0 \\
26.3 \\
29.0 \\
33.2\end{array}$ & $\begin{array}{l}3.0 \\
5.6 \\
2.6\end{array}$ & Child not gaining \\
\hline Average...... & .......... & $\overline{36.6}$ & 33.1 & 47.2 & 19.7 & & \\
\hline
\end{tabular}

* These were normal infants but they were suffering from slight temporary indisposition.

The second group, Table 2 , shows the findings in good stools which were not quite normal in appearance; that is, they were partly green in color or showed some mucus, or had both these characteristics.

In this group the total fat per cent. is somewhat lower than in the first group, the average being 36.6 per cent. of the dried weight; there are only two instances in which it is over 50 per cent., while in two it 
is under 20 per cent. A marked contrast between this table and the preceding appears in the change in the proportions of free fatty acids and soap fat. In the second group the fatty acids are high, averaging 47.2 per cent. of the total fat, while the soap average is only 33.1 per cent. In two-thirds of the cases the fatty acid is the predominating form in which the fat is found in the stood. In this group the neutral fat averages somewhat higher than in the preceding group, it being 19.7 per cent. of the total fat.

Table 3 presents the analyses of a group of stools which might be considered distinctly abnormal; that is, entirely green or containing much mucus.

Table 3.-Total Fat and Fat Distribution in Stools Which Were Entirely Green or Contained Much Mucus

\begin{tabular}{|c|c|c|c|c|c|c|c|}
\hline \multirow[b]{2}{*}{ Case } & \multirow[b]{2}{*}{ Age } & \multirow{2}{*}{$\begin{array}{c}\text { Fat } \\
\text { per Cent. } \\
\text { of } \\
\text { Dried } \\
\text { Weight }\end{array}$} & \multicolumn{3}{|c|}{ Per Cent. of Total Fat as } & \multirow{2}{*}{$\begin{array}{c}\text { Per } \\
\text { Cent. } \\
\text { Fat in } \\
\text { Mother's } \\
\text { Milk }\end{array}$} & \multirow[b]{2}{*}{ Remarks } \\
\hline & & & Soap & $\begin{array}{c}\text { Free } \\
\text { Fatty } \\
\text { Acids }\end{array}$ & $\underset{\text { Fat }}{\text { Neutral }}$ & & \\
\hline 32. H. S. 4 & 11 wk. & 18.1 & 51.9 & 37.4 & 10.7 & & \\
\hline 33. J. F. & $10 \mathrm{mo}$. & 12.4 & 51.6 & 24.5 & 23.9 & 3.8 & $\begin{array}{l}\text { Child in excellent condi- } \\
\text { tion; sugar in milk, } \\
6.6 \%\end{array}$ \\
\hline 34. B. S. & $10 \mathrm{wk}$. & 4.4 & 49.9 & 40.0 & 10.1 & 4.9 & Child gaining: much \\
\hline 35. M. S. 3 & $10 \mathrm{wk}$. & 35.0 & 45.2 & 35.6 & 19.2 & $\ldots$ & Chalk mixture for 10 \\
\hline $\begin{array}{l}\text { 36. } \\
\text { 37. } \\
\text { H. T. S. } 5\end{array}$ & 6 wk. & 31.7 & 44.3 & 34.3 & 21.4 & 4.4 & Much mueus in stool \\
\hline & & & & & & $\cdots$ & preceding \\
\hline 38. E. M. 2 & $12 \mathrm{wk}$. & 8.8 & 37.0 & 30.0 & 33.0 & 5.8 & $\begin{array}{l}\text { Stool normal except for } \\
\text { much mucus }\end{array}$ \\
\hline $\begin{array}{l}\text { 39. E. M. } \\
\text { 40. J. W. }\end{array}$ & $\begin{array}{l}3 \mathrm{mo} . \\
7 \mathrm{mo} .\end{array}$ & $\begin{array}{l}38.3 \\
14.1\end{array}$ & $\begin{array}{l}36.8 \\
34.4\end{array}$ & $\begin{array}{l}31.3 \\
35.7\end{array}$ & $\begin{array}{l}31.9 \\
29.9\end{array}$ & $\begin{array}{l}3.9 \\
\cdots\end{array}$ & $\begin{array}{l}\text { Stool very green } \\
\text { Child gaining slowly; }\end{array}$ \\
\hline 41. J. M. & $4 \mathrm{mo}$ & 14.4 & 34.2 & 34.3 & 31.5 & 1.0 & $\begin{array}{l}\text { Child gaining slowly; } \\
\text { sugar in milk, } 5.4 \%\end{array}$ \\
\hline 42. H. S. 2 & $8 \mathrm{wk}$. & 18.2 & 27.8 & 23.9 & 48.3 & $\cdots$ & $\begin{array}{l}\text { Stool extremely acid } \\
\text { with much mueus }\end{array}$ \\
\hline 43. P. W. & $9 \mathrm{wk}$. & 40.3 & 26.0 & 41.9 & 32.1 & $\cdots$ & Stool very green with \\
\hline 44. H. S. 1 & 5 wk. & 32.3 & 12.3 & 64.7 & 23.0 & 3.4 & Stool extremely acid \\
\hline Average.. & & 23.0 & 37.7 & 36.7 & 25.6 & & \\
\hline
\end{tabular}

The most striking feature in this table is the low per cent. of total fat, averaging 23.0 per cent. of the dried weight. In more than half the cases it is below 20 per cent. Since many of these stools consisted very largely of mucus, it is probable that the low fat per cent. is thus to be explained. The two very low figures for total fat in Table 2 may be accounted for in the same way. This type of stool is usually an indication of an abnormal intestinal condition, and under such circumstances the total daily excretion of feces is considerably increased over the normal. Hence the total daily loss of fat would be greater than occurs in children with normal stools in which the per cent. of fat is higher.

When the distribution of the fat in Table 3 is considered, it is seen that the per cent. of neutral fat is much higher than in the other 
two groups, averaging 25.6 per cent. of the total fat. The average per cent. of the soap and that of the fatty acids are about the same. The five stools in which soap predominated contained much mucus, and all but one were otherwise normal in appearance.

The case, H. S., was followed for some weeks, five stools being examined. The child was well nourished and gaining normally, but had extremely acid stools, with considerable mucus, and she had a severe excoriation of the buttocks. An effort was made to reduce the acidity of the stools by the administration of chalk mixture. Observations 44 and 42 were made before any chalk mixture was given and show very low soap per cent. Before Observations 35 and 37 the child received an ounce of chalk mixture daily for over a week, with the result that the soap fat of the stools was markedly increased. Although no chalk mixture was given just before Observation 32 , the effect of the preceding administration seems to have persisted.

The average of the analyses of the stools of all the children in good condition, 44 observations, included in the three tables just discussed, is as shown in Table 4.

TABLE 4.-Average Analyses of Stools

\begin{tabular}{cccc}
\hline \hline $\begin{array}{c}\text { Fat of Stool, } \\
\text { per Cent. of } \\
\text { Dried Weight } \\
34.5\end{array}$ & $\overbrace{\text { Soap }}^{43.1}$ & Pree Fatty Acids & Nentral Fat \\
& & 36.7 & 20.2
\end{tabular}

This may be taken to represent an average stool of the breast fed infant in good condition.

It must be borne in mind that this average includes the analyses of not only the typically normal stools, but others not quite normal and some that were markedly abnormal in appearance. It is the more striking, therefore, that the fat constitutes over one-third of the dried weight and that the soap is over 40 per cent. of the total fat. Even when allowance is made for an increase in the proportion of soap which takes place during drying, the average soap fat is found to form at least one-third of the total fat of the stool.

Table 5 presents the results of the examination of the stools of four infants who were seriously ill.

Two observations show very high per cent. of total fat, in stools which were very different in appearance. One was large, green and watery; the other was approximately normal in appearance, but the daily amount was large. In both the per cent. of total fat is about the same as in a number of the normal stools, but the abnormal character is shown in the distribution of the fat. The soap is extremely low, much lower than is found in the stools of normal infants. The neutral fat and the fatty acids are both very high. The other two 
cases show a very low percentage of total fat. The stools were green, watery and contained much mucus. Both these infants had a very low fat intake. One child was so ill that he nursed very little, and the other received milk with a very low fat content. In the stools of both these infants the soap per cent. of total fat is also very low.

A study of Tables 1 to 5 suggests an answer to two of the questions stated in the beginning of the paper, first, the normal per cent. of total fat and the distribution of the fat as soap, free fatty acids and neutral fat, and, second, the difference in fat content and distribution between normal and abnormal stools.

The fat per cent. of dried weight of the normal stools is high, usually over 30 per cent., and frequently reaches 50 or 60 per cent. with infants whose digestion is excellent. As the stools depart from the normal the per cent. of fat usually diminishes. When the fat per cent. is low it may be suspected that the stool contains an abnormal amount of mucus.

TABLE 5.-Total Fat and Fat Distribution in Stools of Sick Infants

\begin{tabular}{|c|c|c|c|c|c|c|c|c|}
\hline & \multirow[b]{2}{*}{ Case } & \multirow[b]{2}{*}{ Age } & \multirow{2}{*}{$\begin{array}{l}\text { Fat } \\
\text { per Cent. } \\
\text { of } \\
\text { Dried } \\
\text { Weight }\end{array}$} & \multicolumn{3}{|c|}{ Per Cent. of Total Fat as } & \multirow{2}{*}{$\begin{array}{c}\text { Per } \\
\text { Cent. } \\
\text { Fat in } \\
\text { Mother's } \\
\text { Millk }\end{array}$} & \multirow[b]{2}{*}{ Remarks } \\
\hline & & & & Soap & $\begin{array}{l}\text { Free } \\
\text { Fatty } \\
\text { Acids }\end{array}$ & $\begin{array}{l}\text { Neutral } \\
\text { Fat }\end{array}$ & & \\
\hline & J. D. & $8 \mathrm{mo}$. & 57.1 & 11.0 & 56.3 & 32.7 & 3.4 & Ileocolitis, scurvy; stool \\
\hline & H. F. & $6 \mathrm{mo}$. & 53.7 & 6.6 & 49.6 & 43.8 & 4.5 & $\begin{array}{l}\text { Eezema, diarrhea; stool } \\
\text { green, watery, fat } \\
\text { curds, mucus }\end{array}$ \\
\hline & o. v. & $5 \mathrm{mo}$. & 17.2 & 20.5 & (No sep & aration) & 0.9 & $\begin{array}{l}\text { Eczema, erysipelas, diar- } \\
\text { rhea; gtool green } \\
\text { watery stol }\end{array}$ \\
\hline 48. & J. B. & $7 \mathrm{mo}$. & 17.0 & 29.2 & 42.7 & 28.1 & ... & $\begin{array}{l}\text { Syphilitic, temporarily } \\
\text { very ill from reaction } \\
\text { after salvarsan; child } \\
\text { was well nourished }\end{array}$ \\
\hline
\end{tabular}

In the best stools the soap fat regularly exceeds in amount the other forms of fat and constitutes on the average nearly half the fat of the stool. Folin and Wentworth ${ }^{2}$ have called attention to the possibility that during the process of drying a moist acid stool on a waterbath, a change may take place in the relation of the free fatty acids and the soaps, as a result of the volatilization of the lower acids, derived from sugar, such as lactic and acetic acids. On this account we have analyzed for comparative study a large quantity of composite stool obtained from about twelve breast fed infants. This composite stool appeared to be fairly representative of normal and nearly normal stools. It was found that although there is an increase of soap at the expense of the free fatty acids in the dried specimen, yet this difference is not great enough to alter our conclusion, founded on the analysis of the dried stools, namely, that in the best stools of breast fed infants the

2. Folin and Wentworth: Jour. Biol. Chem. 6:421, 1910. 
soap fat predominates over the other forms of fat. The results of the analyses of the composite stool, part of which was examined fresh and part of which was analyzed after drying on the waterbath, are as in Table 6.

In very acid stools which show even when dried a very low per cent. of soap, the difference between the analyses of the moist and dried material might be even greater than was found in the above-mentioned sample. In an alkaline composite stool, from children fed on cow's milk dilutions, no change in the distribution of soap and free fatty acids was caused by the drying process.

The increased difficulty of manipulation and the inconvenient necessity of making analyses immediately make it less desirable to work with the fresh stool. Hence, the use of dried material is more practicable, but the results must be interpreted with due consideration for the effect of drying on the relative proportions of free fatty acids and soap. From the foregoing investigation it would seem that, on the average, the soap value as determined in the dried stool should be decreased by about 10 per cent. of the total fat and the fatty acids correspondingly increased in order to represent conditions in the fresh stool.

TABLE 6.-Analysis of Composite Stool

\begin{tabular}{|c|c|c|c|c|}
\hline & \multirow{2}{*}{$\begin{array}{c}\text { Fat per Cent. } \\
\text { of Dried } \\
\text { Weight }\end{array}$} & \multicolumn{3}{|c|}{ Per Cent. of Total Fat as } \\
\hline & & Soap & Free Fatty Acids & Neutral Fat \\
\hline 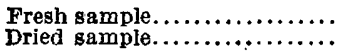 & $\begin{array}{l}44.6 \\
46.3\end{array}$ & $\begin{array}{l}44.6 \\
55.8\end{array}$ & $\begin{array}{l}35.9 \\
25.4\end{array}$ & $\begin{array}{l}19.5 \\
18.8\end{array}$ \\
\hline
\end{tabular}

The neutral fat is normally less than 20 per cent. of the total fat. When the proportion of neutral fat is much higher than 20 per cent., an abnormal intestinal condition is indicated.

The variation in the fatty acids is striking. As the stools depart slightly from the normal the fatty acids are found to be increased at the expense of the soap fat; in those which are markedly abnormal the neutral fat is raised at the expense of the free fatty acids.

Abnormal stools are of two classes with respect to fat content: (1) Those containing much mucus with a low per cent., and (2) diarrheal stools, in which the fat per cent. is high, the result of poor absorption. Under abnormal conditions the per cent. of total fat which is soap is regularly low, while the neutral fat is high.

In thirty-two of the cases studied the per cent. of fat in the mother's milk was determined. ${ }^{3}$ These figures are incorporated in Tables 1 to 5 .

\footnotetext{
3. A slight modification of the Babcock method was used to determine the fat per cent. of breast milk. It was found that when 17.6 c.c. of sulphuric acid, which is the rule in determining the fat of cow's milk, was used with breast milk the fat became charred and did not give a clear separation. If the amount of acid is reduced to 13 or 14 c.c. a clear separation of fat is obtained.
} 
No constant relation is shown between the percent. of fat in the milk and the per cent. and distribution of fat in the stool. There is possibly a slightly higher fat per cent. in the stools of the infants who were receiving milk higher in fat, but the distribution of the fat of the stool does not seem to be influenced by the per cent. of fat in the milk taken.

In only 13 cases was the exact daily intake of fat known. These are shown in Table 7 .

TABLE 7.-Relation of Fat Intake to Fat Excretion and Distribution in the Stool

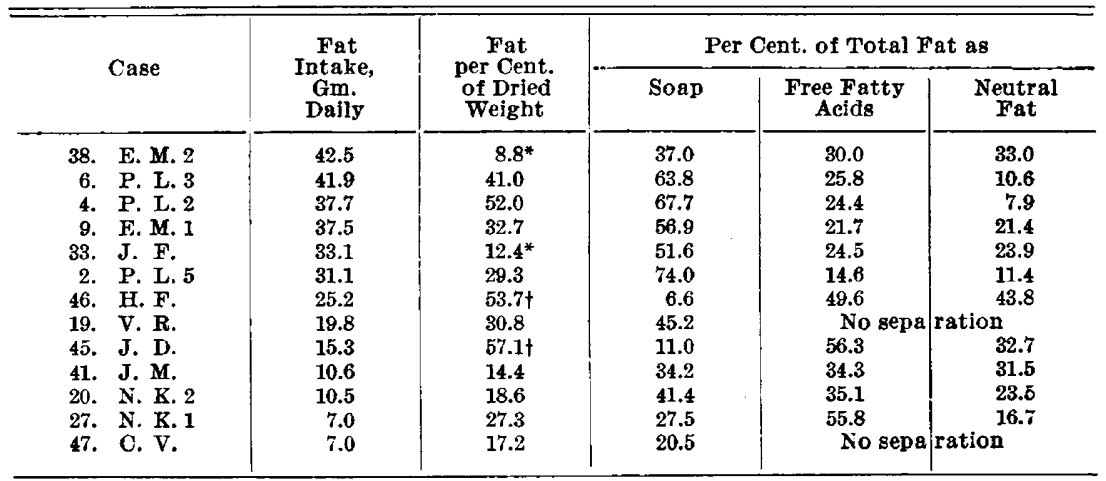

* Stool contained considerable mueus.

† Infant was very ill.

In the cases where the fat intake is high there is a somewhat higher per cent. of total fat in the stool and a higher proportion of the fat as soap than in the other cases with lower fat intake. The only marked exceptions to this are two instances in which a large proportion of the stool was mucus and two others in which the children were very ill. In general, the stools are more nearly normal when the fat intake is high. In other words, the normal condition in breast fed infants seems to be a high fat intake.

In eleven instances not only was a record of the exact daily fat intake obtained, but the stools were collected for definite periods, twenty-four or forty-eight hours. It is to be regretted that this number is so small, for there is need of more exact knowledge in regard to the absorption of fat by breast fed infants. Various investigators, Michel, Keller, Rubner and Heubner, Freund, Uffelmann, Nobécourt and Merklin, report figures for fat absorption ranging from 92 to 99 per cent. This range is similar to that found in our cases. Table 8 presents the findings in eight observations on six normal infants and shows a range in absorption from 90.3 to 99.2 per cent. of the fat intake, and an average of 95.1 per cent. 
TABLE 8.-Absorption of Fat by Normat. Breast Fed Infants

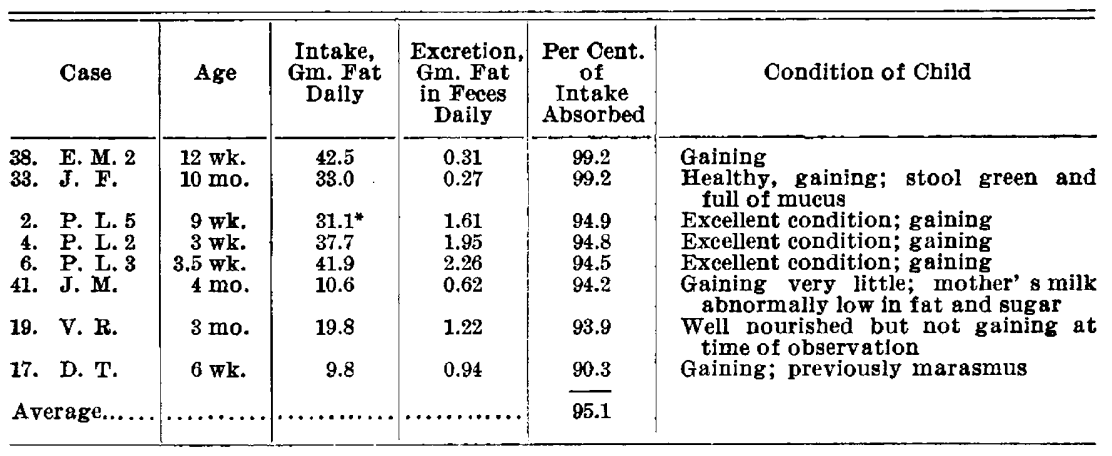

* 4.3 grams fat from small amount of formula.

In contrast to the foregoing, Table 9 shows how fat absorption is reduced under abnormal conditions. The three observations reported in this table werè upon children acutely ill.

Attention should be called to the high intake in five of the cases in Table 8 . With over $30 \mathrm{gm}$. of fat daily, all the children were gaining well and their subsequent progress was entirely satisfactory. An intake of $41.9 \mathrm{gm}$. of fat daily at the age of $3 \frac{1}{2} 2$ weeks, as in Observation 6, might be thought excessive, but this infant had stools entirely normal, and his condition was at the time, and continued to be, excellent.

The great loss of fat under abnormal intestinal conditions is shown by two of the observations in Table 9 . One child, who was very sick with ileocolitis, but whose stools were not loose at the time, had a daily loss in the stool of $5.7 \mathrm{gm}$. of fat. Another child with severe diarrhea lost $12 \mathrm{gm}$. of fat daily in the stool.

TABLE 9.-Absorption of Fat by Sick Breast Fed Infants

\begin{tabular}{|c|c|c|c|c|c|}
\hline Case & Age & $\begin{array}{l}\text { Intake, } \\
\text { Gm. Fat } \\
\text { Daily }\end{array}$ & $\begin{array}{c}\text { Excretion, } \\
\text { Gm. Fat } \\
\text { in Feces } \\
\text { Dally }\end{array}$ & $\begin{array}{c}\text { Per Cent. } \\
\text { of } \\
\text { Intake } \\
\text { Absorbed }\end{array}$ & Condition of Child \\
\hline 47. C. V. & $5.5 \mathrm{mo}$. & 7.0 & 1.48 & 79.0 & $\begin{array}{l}\text { Not gaining; eczema and diarrhea; } \\
\text { mother's milk very low in fat }\end{array}$ \\
\hline $\begin{array}{l}\text { 45. J. D. } \\
\text { 46. H. F. }\end{array}$ & $\begin{array}{l}8 \mathrm{mo} . \\
6 \mathrm{mo} .\end{array}$ & $\begin{array}{l}15.7 \\
25.2\end{array}$ & $\begin{array}{r}5.71 \\
12.00\end{array}$ & $\begin{array}{l}62.6 \\
52.5\end{array}$ & $\begin{array}{l}\text { Ileocolitis } \\
\text { Acute diarrhea }\end{array}$ \\
\hline
\end{tabular}

In the literature of the fat metabolism of infants emphasis is frequently laid on the point that a high proportion of fat and particularly of soap fat in the stools is to be looked on as unfavorable. This belief is apparently based on the assumption that the stools of healthy breast fed infants, taken as a normal standard, contain a low per cent. of fat, comparatively little of which is in the form of soap. The results obtained by us with so considerable a number of healthy breast fed infants are entirely at variance with this view. 


\section{CONCLUSIONS}

1. The fat of the stools of normal breast fed infants, according to our observations, averaged 34.5 per cent. of the dried weight and frequently was as high as 50 per cent.

2. The soap fat in the best stools predominated over the other forms of fat, averaging 57.8 per cent. of the total fat, as determined on the dried stool. The average stool of the normal breast fed infants showed a soap fat of 43.1 per cent. of the total fat, as determined on the dried stool, which would correspond to over one-third of the total fat of the fresh stool.

3. The neutral fat in the best stools averaged 15.9 per cent. of the total fat; in the average stool the neutral fat was 20.2 per cent. of the total fat. The amount of neutral fat is not affected by the drying process.

4. No constant relation was shown between the per cent. of fat in the mother's milk and the per cent. of total fat and its distribution in the stool.

5. With a higher total intake of fat, the fat per cent. and the soap fat in the stool were somewhat increased.

6. A range of fat absorption from 90.3 to 99.2 per cent. of the intake was found in healthy breast fed infants.

We wish to acknowledge our thanks to the physicians of the New York Foundling Hospital and the Vanderbilt Clinic, and to the visiting physicians of the Babies' Hospital for their kind assistance in collecting stools. 